ARTIKEL PENELITIAN

\title{
TINGGI IBU SEBAGAI DETERMINAN STUNTING PADA BALITA DI KALIMANTAN TIMUR
}

\author{
Nino Adib Chifdillah ${ }^{1)}$, Kurniati Dwi Utami ${ }^{2)}$, Ratnawati ${ }^{3)}$ \\ ${ }^{1}$ Jurusan Kebidanan, Poltekkes Kemenkes Kaltim, Jalan W. Monginsidi No. 38, \\ Samarinda, 75123 \\ 2,3) Jurusan Gizi, Poltekkes Kemenkes Kaltim, Jalan Kurnia Makmur No. 64, \\ Samarinda, 75131 \\ E-mail: nynology@gmail,com
}

\begin{abstract}
Indonesia is country with the fourth highest prevalence of stunting among under 5-years old children in the world and the second highest of that in Southern Asia. Maternal factors is so important because they become the main determinants and source of stunting prevention. This research aimed to analyze the sociodemography, parenting and food intake of mother as determinant of stunting. The research was cross sectional study with 97 under 5-years old children in chosen Posyandu. Measurement of body height of mother and under 5-years old children who had stood by microtoise. Meanwhile measurement of under 5-years old children who had not stood by length board. There were three variables related to stunting among under 5-years old children. They are parity ( $\mathrm{p}$-value $=0,017$ ), the height of mother (p-value $=0,009)$ and the level of income ( $p$-value=0,036). The most dominant variable related to stunting among under 5-years old children was the height of mother $(\mathrm{OR}=3,1)$. Determinants of stunting among under 5-years old children were parity, height of mother and the level of income.
\end{abstract}

Keywords: stunting, under 5-years old children, height of mother

\begin{abstract}
Abstrak
Indonesia adalah negara dengan prevalensi balita stunting terbesar keempat di dunia dan tertinggi kedua di wilayah Asia Tenggara. Faktor ibu layak menjadi perhatian karena menjadi determinan dan sumber utama pencegahan stunting. Penelitian ini bertujuan untuk menganalisis faktor sosiodemografi ibu, pola asuh dan asupan makanan sebagai determinan stunting. Desain penelitian ini adalah cross sectional dengan jumlah sampel 97 balita yang terdaftar di Posyandu. Pengukuran tinggi badan ibu dan balita yang sudah bisa berdiri menggunakan microtoise. Sementara pengukuran panjang badan balita yang belum bisa berdiri menggunakan length board. Terdapat tiga variabel yang berhubungan dengan kejadian stunting pada balita. Ketiga variabel tersebut adalah paritas ( $p$-value $=0,017$ ), tinggi badan ibu ( $\mathrm{p}$-value $=0,009)$ dan tingkat pendapatan ( -value=0,036). Variabel yang paling dominan berhubungan dengan kejadian stunting pada balita adalah tinggi badan ibu $(\mathrm{OR}=3,1)$. Determinan stunting balita antara lain faktor paritas, tinggi badan ibu dan tingkat pendapatanAbstrak dalam Bahasa Indonesia.
\end{abstract}

Kata Kunci: stunting, balita, tinggi badan ibu 
Mahakam Midwifery Journal, Vol 2, No. 5, Mei 2019 : 337-347

PENDAHULUAN

Stunting telah menjadi masalah kesehatan masyarakat global. Laporan hasil survey antara WHO, UNICEF dan World Bank Group (2016) mengestimasikan bahwa terdapat 155 juta kasus stunting di dunia. Jumlah balita stunting dari laporan tersebut mencapai 154,8 juta atau $22,9 \%$ dari total keseluruhan yang mana sebagian besar terjadi di negara-negara berkembang di benua Asia. Indonesia adalah negara berkembang di Asia dengan prevalensi kasus balita stunting yang sangat tinggi. Data Global Nutrition Report (2017) menyebutkan persentase prevalensi balita stunting di Indonesia mencapai 36,4\% yang menempatkan Indonesia sebagai negara dengan prevalensi balita stunting tertinggi ke-24 di dunia. Selain itu, persentase tersebut menjadikan Indonesia sebagai negara dengan prevalensi balita stunting tertinggi kedua di Asia. Hal ini juga didukung hasil Riset Kesehatan Dasar tahun 2007 hingga 2013 (Kementerian Kesehatan, 2013).

Prevalensi stunting pada balita yang tinggi harus menjadi perhatian oleh berbagai pihak dan program. Hal ini dikarenakan stunting akan menyebabkan dampak negatif pada berbagi aspek kehidupan manusia. Tim Nasional Percepatan Penanggulangan
Kemiskinan menjelaskan bahwa balita atau baduta stunting berisiko mengalami reduksi kecerdasan kognitif, resistensi berbagai penyakit dan degradasi produktivitas kerja di masa depan. Ketiga dampak negatif ini akhirnya akan menghambat pertumbuhan ekonomi, meningkatkan kemiskinan serta memperlebar kesenjangan status sosial sampai pada tingkat nasional (TNP2K, 2013). Berbagai dampak negatif tersebut menekankan pada pentingnya upaya pencegahan stunting pada balita.

Upaya pencegahan stunting akan optimal apabila setiap perencanaan kegiatan yang akan dilaksanakan didahului oleh adanya perencanaan berdasarkan evidence based, misalnya analisis determinan balita stunting. Salah satu konsep yang tepat digunakan untuk menganalisis determinan stunting pada balita adalah Conceptual Framework of The Determinants of Child Undernutrition yang disusun UNICEF. Konsep ini menjelaskan bahwa terdapat tiga penyebab stunting pada balita. Ketiga penyebab tersebut ialah penyebab dasar, penyebab tidak langsung dan penyebab langsung yang bersifat kausatif. Penyebab dasaar meliputi faktor sosiobudaya, ekonomi dan politik. Penyebab tak langsung terdiri dari aksessibilitas pangan dan pola asuh. Sementara penyebab langsung balita 
Mahakam Midwifery Journal, Vol 2, No. 5, Mei 2019 : 337-347

stunting adalah asupan gizi dan penyakit infeksi (UNICEF, 2015).

Kalimantan Timur adalah Provinsi dengan prevalensi stunting pada balita paling rendah keempat di Indonesia dengan persentase $27,6 \%$. Prevalensi balita stunting di Kalimantan timur juga mengalami penurunan selama tiga periode pelaksanaan Riset Kesehatan dasar. Prevalensi stunting pada balita tahun 2007 sebesar 35,2\% lalu turun menjadi 29,1\% tahun 2010 dan 27,6\% pada tahun 2013 (Kementerian Kesehatan, 2013). Persentase prevalensi balita stunting di Kalimantan Timur tersebut telah berada di bawah rerata persentase prevalensi nasional (37,2\%). Namun hal ini masih menjadi masalah kesehatan karena masih di atas standar yang ditetapkan WHO yaitu $20 \%$ atau lebih (Trihono, dkk, 2015). Berdasarkan uraian tersebut, perlu adanya penelitian yang bertujuan khusus untuk menganalisis determinan stunting pada balita di Kalimantan Timur. Hasil penelitian ini diharapkan bisa menjadi data informasi tambahan bagi perencanaan program pencegahan dan penurunan kasus stunting pada balita di Kalimantan Timur.

\section{METODE PENELITIAN}

Penelitian ini menggunakan pendekatan kuantitatif, berjenis penelitian analitik non- eksperimental dengan desain cross sectional. Penelitian ini berlangsung dari bulan September sampai November 2018 di Wilayah Kerja Puskesmas Baqa, Samarinda Kota. Pemilihan lokasi penelitian berdasarkan laporan Tim Nasional Pengentasan Kemiskinan tentang 100 Kabupaten/Kota Prioritas Intervensi Stunting Tahun 2016. Penentuan jumlah sampel menggunakan uji proporsi satu populasi teknik purposif sehingga dibutuhkan 97 responden yang dipilih secara purposif. Pengumpulan data melalui pengisian lembar kuesioner berisi 20 soal yang sebelumnya telah diuji validitas dan reliabilitasnya. Analisis data penelitian terdiri dari analisis bivariat melalui uji Pearson Chi-Square dan analisis multivariat melalui regresi logistik ganda.

\section{HASIL DAN PEMBAHASAN}

Peneliti melakukan pengumpulan data di empat Posyandu yang telah didiskusikan dengan petugas gizi Puskesmas Baqa dengan dasar penyesuaian waktu pelaksanaan Posyandu. Empat Posyandu tersebut a Posyandu Menur A, Posyandu Menur B, Posyandu Ramania dan Posyandu Keledang. Peneliti datang bersama petugas gizi Puskesmas Baqa dan tim enumerator di setiap Posyandu yang telah ditetapkan. Peneliti dan petugas gizi Puskesmas Baqa menjelaskan maksud kedatangan pada kader 
Mahakam Midwifery Journal, Vol 2, No. 5, Mei 2019 : 337-347

Posyandu dan kemudian meminta izin untuk melakukan pengumpulan data. Hasil membantu proses pelaksanaan Posyandu dan penelitian disajikan pada table berikut.

Tabel 1. Hasil Analisis Bivariat

\begin{tabular}{|c|c|c|c|c|}
\hline \multirow[t]{2}{*}{ Variabel } & \multicolumn{2}{|c|}{ Status Gizi Balita } & \multirow[t]{2}{*}{ p-value } & \multirow[t]{2}{*}{ Keterangan } \\
\hline & Stunting & Normal & & \\
\hline
\end{tabular}

\section{Karakterisitik Demografi}

1. Umur Ibu

$\begin{array}{lllll}<20 \text { atau }>35 \text { tahun } & 12 & 20 & 0,507 & \text { Tidak ada hubungan } \\ 20 \text { sampai } 35 \text { tahun } & 20 & 45 & & \\ \text { Tinggi Badan Ibu } & & & & \\ \leq 145 \mathrm{~cm} & 17 & 17 & 0,009 * & \text { Ada hubungan } \\ >145 \mathrm{~cm} & 15 & 48 & & \end{array}$

3. Tingkat Pendidikan Ibu

$\begin{array}{lllll}\text { Rendah } & 20 & 29 & 0,098 & \text { Tidak ada hubungan } \\ \text { Tinggi } & 12 & 36 & & \end{array}$

4. Tingkat Pendapatan Keluarga

Rendah

22

Tinggi

10

30

0,036*

Ada hubungan

5. Umur Ibu

Tidak ideal

$18 \quad 28$

0,222

Tidak ada hubungan

Ideal

14

37

\section{Pola Asuh Ibu}

1. Pemberian ASI

Tidak eksklusif

Eksklusif

$21 \quad 25 \quad 0,012 * \quad$ Ada hubungan

$11 \quad 40$

2. Kunjungan Imunisasi Dasar

Tidak lengkap

Lengkap

$19 \quad 20$

$0,007 *$

Ada hubungan

$13 \quad 45$

\section{Asupan Makanan}

1. Tingkat Aupan Makanan

Rendah

$\begin{array}{llll}16 & 15 & 0,010 * & \text { Ada hubungan } \\ 9 & 17 & \\ 7 & 33 & \end{array}$

Sumber: Data primer terolah, 2018

* Ada hubungan setelah dianalisis dengan Uji Chi-Square

Tabel 2. Hasil Analisis Multivariat 


\begin{tabular}{lcccccccc}
\hline Variabel & B & S.E. & Wald & df & Sig. & Exp (B) & 95\% CI for Exp (B) \\
\hline Tinggi badan ibu & 1,287 & 0,489 & 6,936 & 1 & $0,008^{*}$ & 3,621 & 1,390 & 9,435 \\
Asupan makanan & 0,854 & 0,284 & 9,043 & 1 & 0,003 & 2,349 & 1,436 & 4,097 \\
Constant & 3,077 & 1,053 & 8,533 & 1 & 0,003 & 0,046 & & \\
\hline
\end{tabular}

Sumber: Data primer terolah, 2018

* Variabel yang paling dominan setelah dianalisis dengan regresi logistik ganda

Hubungan antara Karakteristik yang menunjukan bahwa tidak ada

\section{Demografi dengan Stunting pada Balita}

Berdasarkan tabel 1 dapat diketahui bahwa sebagian besar ibu yang melahirkan pada umur di bawah 20 tahun atau di atas 35 tahun memilikki balita stunting $(69,2 \%)$. Hasil analisis statistik menunjukan bahwa tidak ada hubungan antara umur ibu saat melahirkan dengan status sttunting pada balita. Hal tersebut ditunjukkan dengan nilai p-value 0,507 ( $\mathrm{p}>0,05)$ melalui uji ChiSquare. Sebagian besar ibu yang memiliki tinggi badan pendek $(<145 \mathrm{~cm})$ memiliki balita stunting $(53,1 \%)$. Hasil analisis statistik dengan uji Chi-Square menunjukan ada hubungan antara tinggi badan ibu dengan status stunting pada balita dengan nilai $p$-value sebesar 0,009 ( $\mathrm{p}<0,05)$.

Berdasarkan tabel 1 diketahui bahwa sebagian besar ibu yang memilikitingkat pendidikan rendah memiliki balita stunting $(62,5 \%)$. Hasil analisis statistik melalui uji Chi-Square $p$-value sebesar 0,098 (p > 0,05) hubungan antara tingkat pendidikan dengan stunting pada balita. Sebagian besar ibu yang memiliki tingkat pendapatan rendah memiliki balita stunting (68,8 Hasil analisis statistik menunjukan bahwa ada hubungan antara tingkat pendidikan keluarga dengan status stunting pada balita. Hal tersebut ditunjukkan dengan nilai p-value sebesar 0,036 ( $\mathrm{p}<0,05)$ melalui uji Chi-Square. Sebagian besar ibu yang hidup dengan jumlah keluarga kurang ideal (lebih dari 4 orang) memiliki balita stunting $(56,2 \%)$. Hasil analisis statistik dengan uji Chi-Square menunjukan bahwa tidak ada hubungan antara jumlah anggota keluarga dengan status stunting pada balita dengan nilai $p$ value sebesar 0,222 ( $\mathrm{p}<0,05)$.

\section{Hubungan antara Pola Asuh Ibu dengan} Stunting pada Balita

Berdasarkan tabel 1 diketahui bahwa sebagian besar ibu yang tidak memberikan ASI eksklusif memiliki balita stunting 
Mahakam Midwifery Journal, Vol 2, No. 5, Mei 2019 : 337-347

(61,5\%). Hasil uji Chi-Square menghasilkan p-value sebesar 0,012 yang berarti bahwa secara statistik terdapat hubungan antara pemberian ASI dengan kejadian stunting pada balita. Sementara itu, sebagian besar ibu yang tidak melakukan imunisasi dsar lengkap juga memiliki balita dengan status stunting (69,2\%). Hasil analisis statistik melalui uji Chi-Square menghasilkan pvalue sebesar 0,007 yang berarti bahwa terdapat hubungan antara imunisasi dasar dengan kejadian stunting pada balita.

\section{Hubungan antara Asupan Makanan} dengan Stunting pada Balita

Berdasarkan tabel 1 diketahui bahwa sebagian besar ibu yang memberikan asupan makanan rendah memiliki balita stunting (50,8\%). Hasil uji Chi-Square menghasilkan p-value $=0,010$ yang berarti bahwa secara statistik terdapat hubungan antara asupan makanan dengan kejadian stunting pada balita.

\section{Variabel yang Paling Dominan Berhubungan dengan Status Stunting pada Balita}

Berdasarkan tabel 2 diketahui bahwa hasil analisis multivariat dengan regresi logistik ganda menunjukkan terdapat 2 (dua) variabel yang secara bersama signifikan berhubungan dengan kejadian stunting pada balita. Kedua variabel tersebut adalah tinggi badan ibu (OR 3,6, CI: 1,390-9,345) dan asupan makanan (OR 2,3, CI: 1,436-4,097). Berdasarkan hasil tersebut, dapat diketahui bahwa faktor yang paling berhubungan dengan kejadian stunting balita adalah tinggi badan ibu karena memiliki nilai OR paling besar yaitu 3,6. Hal ini berarti bahwa balita yang memiliki ibu dengan tinggi badan pendek berisiko 3,6 kali lebih besar untuk mengalami stunting setelah dikontrol dengan variabel asupan makanan.

\section{Pembahasan}

Hasil penelitian ini menunjukkan bahwa tidak ada hubungan antara umur ibu dengan kejadian stunting pada balita. Umur adalah faktor sosiodemografi yang bisa mempengaruhi tingkat pengetahuan seseorang. Pengetahuan kemudian akan membentuk perilaku, termasuk perilaku kesehatan. Selain itu, umur adalah salah satu faktor sosiodemografi yang termasuk penyebab dasar terjadinya gizi buruk pada bayi dan balita. Penyebab dasar adalah faktor-faktor yang menjadi dasar dan awal terjadinya gizi buruk pada bayi dan balita, seperti faktor sosiobudaya, sosioekonomi dan sosiodemografi. Penyebab dasar lalu membentuk penyebab tidak langsung dan 
Mahakam Midwifery Journal, Vol 2, No. 5, Mei 2019 : 337-347

penyebab langsung terhadap status gizi bayi dan balita. Oleh karena itu, umur ibu sebagai faktor sosio-demografi yang mempengaruhi status balita stunting, yang bersifat relatif dan tidak langsung (UNICEF, 2015). Hal inilah yang menimbulkan relativitas pada faktor umur ibu dalam mempengaruhi status balita stunting.

Hasil penelitian ini menunjukkan bahwa ada hubungan antara tinggi badan ibu dengan kejadian stunting pada balita. Hasil penelitian ini selaras dengan hasil kajian sistematik Riskesdas 2010 oleh Oktarina dan Sudiarti pada 1.239 orang balita di empat Provinsi di Pulau Sumatera yang menyebutkan bahwa ibu dengan tinggi badan di bawah $145 \mathrm{~cm}$ (pendek) berisiko 1,36 kali lebih besar memiliki balita stunting (Oktarina dan Sudiarti, 2015) . Pengaruh faktor genetika terhadap terjadinya stunting adalah 5\% namun meningkat tajam pada masyarakat tingkat ekonomi lemah dan hidup di lingkungan dengan sanitasi buruk. Supariasa (2016) juga menyatakan bahwa anak dari orangtua yang pendek, baik salah satu maupun keduanya, lebih berisiko untuk tumbuh pendek dibandingkan dengan anak dengan orang tua yang memiliki badan tinggi. Hal ini dikarenakan tinggi badan anak merupakan salah satu bentuk ekskpresi genetik orangtua.
Hasil penelitian ini menunjukkan bahwa tidak ada hubungan antara pendidikan ibu dengan kejadian stunting pada balita. Hasil penelitian ini sesuai dengan hasil penelitian Nasution pada 242 orang balita di Yogyakarta yang menyebutkan pendidikan ibu sebagai determinan stunting pada balita (Nasution, 2011). Secara teori, semakin tinggi pendidikan seseorang maka semakin baik pula pengetahuan yang dia miliki. Ibu yang memiliki pengetahuan yang baik tentang gizi dan pertumbuhan anak kemungkinan besar akan menampilkan perilaku sehat sehingga diharapkan membentuk status gizi optimal pada anaknya. Hal ini terkait peran utama ibu sebagai pihak yang bertanggungjawab terkait asupan makanan anak, seperti menentukan jumlah, jenis dan jadwal makan. Tidak adanya hubungan pendidikan ibu dengan status balita stunting bisa terkait pendidikan yaitu penyebab dasar dan masih terdapat faktor langsung dan tak langsung.

Hasil penelitian ini menunjukkan bahwa tidak ada hubungan antara pendapatan keluarga dengan kejadian stunting pada balita. Hasil penelitian ini sesuai dengan hasil penelitian Irwansyah (2016) dan Sari (2016) yang menjelaskan pendapatan keluarga bukan determinan stunting karena berposisi sebagai variabel luar. Keluarga 
Mahakam Midwifery Journal, Vol 2, No. 5, Mei 2019 : 337-347

yang berpendapatan tinggi memiliki kemungkinan lebih besar untuk mencapai status sehat, termasuk tercegah dari risiko melahirkan bayi yang tumbuh sebagai balita stunting. Hal ini karena mereka memiliki uang lebih untuk memilih dan memberikan makanan bernilai gizi tinggi bagi pertumbuhan anak. Balita pada keluarga miskin juga bisa tetap sehat apabila ibu mampu memilih dan mengolah bahan makanan yang murah tetapi bergizi.

Hasil penelitian ini menunjukkan bahwa tidak ada hubungan antara jumlah anggota keluarga dengan kejadian stunting pada balita. Hasil penelitian ini sesuai dengan hasil penelitian Ni'mah dan Muniroh pada 60 balita di Surabaya yang menyebutkan jumlah anggota keluarga bukan determinan balita stunting (Nimah dan Muniroh, 2014). Jumlah anggota keluarga pada dasarnya mempengaruhi status gizi balita karena berhubungan dengan ketersediaan bahan pangan keluarga. Ketersediaan bahan pangan mempengaruhi asupan makanan yag menjadi penyebab langsung masalah status gizi balita. Namun, keluarga dengan tingkat ekonomi rendah dan memiliki jumlah anggota keluarga banyak juga tetap bisa memenuhi ketersediaan bahan pangan keluarga. Hal ini terkait berbagai program bantuan yang diberikan oleh Pemerintah misalnya adanya kartu e-warung.

Hasil penelitian ini menunjukkan bahwa ada hubungan antara pemberian ASI dengan kejadian stunting pada balita. Hasil penelitian ini sesuai hasil penelitian Hairunis dkk di Bima yang menyebutkan nilai odds ratio faktor pemberian eksklusif terhadap kejadian stunting pada balita mencapai 7,3. Pemberian ASI eksklusif termasuk penyebab tidak langsung yang mempengaruhi status gizi bayi. Bayi membutuhkan ASI eksklusif untuk meningkatkan status gizinya selama masa pertumbuhan. Apabila asupannya kurang, maka pertumbuhan dan perkembangannya akan terhambat hingga ia dewasa. Manfaat ASI eksklusif lainnya adalah melindungi bayi dari infeksi mikrobakteri seperti bakteri atau virus. Hal ini penting mengingat ASI mengandung protein khusus yang dapat meningkatkan sistem kekebalan tubuh bayi (Hairunis, Rohmawati dan Ratnawati, 2016).

Hasil penelitian ini menunjukkan bahwa ada hubungan antara imunisasi dasar dengan kejadian stunting pada balita. Hasil penelitian ini sesuai dengan hasil penelitian Rahmad dan Miko (2016) di Banda Aceh bahkan menyatakan bahwa balita yang tidak mendapat imunisasi dasar lengkap berisiko 5,32 kali lebih besar mengalami stunting. 
Mahakam Midwifery Journal, Vol 2, No. 5, Mei 2019 : 337-347

Penyakit infeksi adalah salah satu penyebab langsung terjadinya masalah gizi anak. Pencegahan penyakit infeksi secara tidak langsung akan memutus mata rantai riwayat alamiah stunting anak. Imunisasi adalah salah satu upaya efektif dalam mencegah terjadinya penyakit infeksi melalui proses memberikan kekebalan anak dari penyakit.

Hasil penelitian ini menunjukkan bahwa ada hubungan antara imunisasi dasar dengan kejadian stunting pada balita. Hal ini sesuai dengan teori determinan status gizi ibu dan anak oleh UNICEF (2015) yang menempatkan asupan makanan sebagai penyebab langsung masalah gizi pada anak. Stunting adalah kondisi gagal tumbuh pada anak akibat dari defisiensi gizi kronis dari asupan makanan sehingga anak terlalu pendek untuk usianya. Asupan makanan yang menjadi penyebab langsung masalah stunting karena terkait adanya zat gizi makro dan mikro yang terkandung di dalamnya. Zat gizi makro dan mikro tersebut berperan dalam proses pertumbuhan anak (UNICEF, WHO dan World Bank Group, 2018).

Variabel paling dominan berhubungan dengan kejadian stunting pada balita adalah tinggi badan ibu setelah dikontrol variabel asupan makanan. Probabilitas faktor genetika orang tua dapat mempengaruhi tinggi badan anaknya saat lahir masih rendah adalah sebesar 5-8\%. Sementara faktor lingkungan memiliki kemungkinan lebih besar yaitu mencapai 74-87\% (Beal dkk, 2018). Namun seiring dengan pertambahan umur anak, pengaruh faktor genetika akan semakin meningkat sedangkan pengaruh faktor lingkungan menurun. Hal ini penting mengingat kondisi lingkungan yang sehat akan mendukung pertumbuhan dan perkembangan anak menjadi lebih baik. Tinggi badan merupakan salah satu bentuk dari ekspresi genetik yang diturunkan kepada anak dan menjadi faktor risiko terhadap kejadian stunting. Anak dari orang tua dengan tinggi badan pendek, baik salah satu atau keduanya, lebih berisiko untuk tumbuh pendek atau stunting dibandingkan anak dari orang tua yang memiliki tinggi badan normal. Pada titik inilah, peran faktor asupan makanan sangat dibutuhkan. Hal ini penting mengingat masalah anak stunting di negara maju lebih sering diakibatkan oleh penurunan sifat pendek dari orang tua karena murni adanya sifat gen pendek dalam kromosom orang tua. Sementara penyebab stunting di negara berkembang dan tertinggal cenderung dipengaruhi oleh kombinasi faktor genetika dan lingkungan (Prawirohartono, Nurdiati dan Hakimi, 2016). Tingkat asupan makanan tinggi bisa menjadi intervensi 
Mahakam Midwifery Journal, Vol 2, No. 5, Mei 2019 : 337-347

pencegahan stunting yang disebabkan

kombinasi faktor genetika dan lingkungan yang umumnya terjadi di Indonesia.

\section{SIMPULAN}

Determinan kejadian stunting pada balita di Kalimantan Timur adalah tinggi badan ibu, tingkat pendapatan keluarga, pemberian ASI, imunisasi dasar dan asupan makanan. Sementara faktor yang paling paling dominan berhubungan dengan kejadian stunting pada balita adalah tinggi badan ibu setelah dikontrol variabel asupan makanan..

\section{UCAPAN TERIMA KASIH}

Ucapan terima kasih kami tujukan kepada Unit Penelitian dan Pengabdian kepada Masyarakat Poltekkes Kemenkes Kaltim yang telah mendanai penelitian melalui anggaran DIPA tahun 2018.

\section{DAFTAR PUSTAKA}

Beal T., Tumilowicz A., Sutrisa A., Izwardi D., Neufeld LM. A Review Of Child Stunting Determinants In Indonesia. Journal of Wiley Maternal and Child Nutrition. 2018. 14 : e12617.

UNICEF/WHO/World Bank Group. Levels and Trends in Child Malnutrition: Key Findings of the 2018 Edition of the
Joint Child Malnutrition Estimates. Geneva: World Health Organization. 2018

Development Initiatives. Global Nutrition Report 2017: Nourishing the SDGs. Bristol: UNICEF. 2017

Hairunis MN., Rohmawati N., Ratnawati LY. Determinan Kejadian Stunting pada Anak Balita Di Wilayah Kerja Puskesmas Soromandi Kabupaten Bima Nusa Tenggra Barat. Jurnal Pustaka Kesehatan. 2016. 4(2) : 323:329.

Irwansyah. Kehamilan Remaja dan Kejadian Anak Stunting usia 6-23 Bulan Di Lombok Barat.

Berita Kedokteran Masyarakat. 2016. 32 (6) : $1-8$.

Kementerian Kesehatan Republik Indonesia. Laporan Hasil Riset Kesehatan Dasar (RISKESDAS) Indonesia Tahun 2007. Jakarta: 2007

Kementerian Kesehatan Republik Indonesia. Laporan Hasil Riset Kesehatan Dasar (RISKESDAS) Indonesia Tahun 2010. Jakarta: 2010

Kementerian Kesehatan Republik Indonesia. Laporan Hasil Riset Kesehatan Dasar (RISKESDAS) Indonesia Tahun 2013. Jakarta: 2013 
Mahakam Midwifery Journal, Vol 2, No. 5, Mei 2019 : 337-347

Nasution, D. Berat Badan Lahir Rendah dengan Kejadian Stunting pada Anak Usia 6-24 Bulan. Jurnal Gizi Klinik. 2014. 11 (1): 31-37.

Ni'mah, C., Muniroh, L. Hubungan Tingkat Pendidikan, Tingkat Pengetahuan dan Pola Asuh Ibu dengan Wasting dan Stunting pada Balita Keluarga Miskin. Media Gizi Indonesia. 2015. 10(1) : 84-90

Oktarina, Z., Sudiarti. Faktor Risiko Stunitng pada Balita (24-59 Bulan) Di Sumatera. Jurnal Gizi Pangan. 2015. 8 (3). 175-180.

Prawirohartono EP., Nurdiati, DS., Hakimi, M. Prognosticfactors at birth for stunting at 24 months of age in rural Indonesia. Paediatrica Indonesiana. 2016. 56(1): 48-56.

Rahmad, AH., Miko, A. Kajian Stunting pada Anak Balita Berdasarkan Pola Asuh dan Pendapatan Keluarga Di Kota Banda Aceh. Jurnal Kesmas Indonesia. 2016. 8(2): 275-284.

Sari, EM. Asupan Protein, Kalsium dan Fosfor pada Anak Stunting dan Tidak Stunting Usia 24-59 Bulan. Jurnal Gizi Klinik Indonesia. 2016. 12 (4) : 152159.

Supariasa, IDN. Penilaian Status Gizi. Jakarta. 2016.
Tim Nasional Percepatan Pengentasan Kemiskinan. 100 Kabupaten/Kota Prioritas Untuk Intervensi Stunting. Jakarta. 2013

Trihono, Atmarita, Tjandrarini, Dwi Hapsari. Pendek (Stunting) Di Indonesia, Masalah dan Solusinya. Jakarta. 2015.

United Nations Children's Fund. UNICEF , s Approach To Scaling Up Nutrition. New York. 2015. 